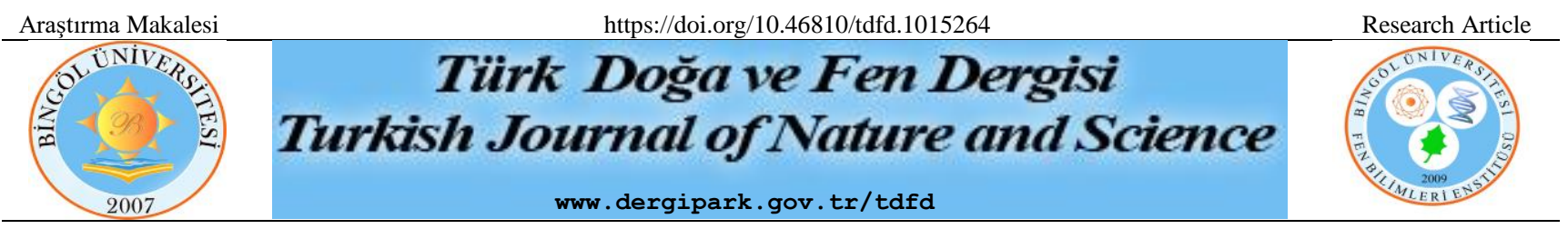

\title{
The Cost of Diaphragm Wall Construction by the Well Method on Cohesive and Non-
} Cohesive Soils

\author{
Gamze BILLGEN ${ }^{1 *}$, Eray AFŞAR ${ }^{2}$ \\ ${ }^{1}$ Zonguldak Bülent Ecevit Üniversitesi, Alaplı MYO, İnşaat Bölümü, Zonguldak, Türkiye \\ ${ }^{2}$ Zonguldak Bülent Ecevit Üniversitesi, Fen Bilimleri Enstitüsü, İnşaat Mühendisliği Bölümü, Zonguldak, Türkiye \\ Gamze BİLGEN ORCID No: 0000-0002-2840-7369 \\ Eray AFŞAR ORCID No: 0000-0002-7874-6326 \\ *Corresponding author: gamzebilgen@beun.edu.tr
}

(Alınış: 27.10.2021, Kabul: 16.11.2021, Online Yayınlanma: 31.12.2021)

Keywords
Diaphragm
wall,
Well method,
Earthquake
risk

Keywords Diaphragm Well method, risk

\begin{abstract}
In this study, the effects of the cohesiveness of the soil in the area where the foundation will be built, and the earthquake risk of the region were examined on the construction costs of the diaphragm wall by the well method. Within the scope of the study, not only the soil in the region is cohesive or non-cohesive, but also the relative density of $0 \%, 50 \%$ or $100 \%$, are discussed. In addition, different earthquake risk conditions such as low, medium or high risk of the region were taken into consideration. Thus, cost analyses were carried out in 27 regions with different conditions for the region where the diaphragm wall construction by the well method will be constructed. In the cost calculations, the Turkish Building Earthquake Code principles and the 2021-unit prices of the Ministry of Environment and Urbanization were used. For the diaphragm wall dimensions and quantity calculations, the IstCAD 2021 software program was used, and analyses were performed for each condition. It was aimed to determine under which conditions the well foundation construction would be more economical by comparing the obtained results with the studies in the literature. The study data advocates that earthquake risk makes significant changes in the costs.
\end{abstract}

\section{Kohezyonlu ve Kohezyonsuz Zeminlerde Kuyu Yöntemi ile İnşa Edilen Diyafram Duvar Maliyeti}

Anahtar
Kelimeler
Diyafram
duvar,
Kuyu
yöntemi,
Deprem riski

Anahtar

Diyafram

duvar,

yöntemi,

Deprem riski
Öz: Bu çalışmada kuyu yöntemi ile yapılan diyafram duvar maliyetlerinde, temelin inşa edileceği bölgede bulunan zeminin kohezyonlu olup olmamasının ve bölgenin deprem riskinin etkileri incelenmiştir. Çalışma kapsamında geoteknik açıdan, bölgedeki zeminin kohezyonlu veya kohezyonsuz olmasının yanı sıra rölatif sıkılığın \%0, \%50 veya \%100 olması gibi etmenler de ele alınmıştır. Ek olarak, bölgenin deprem riskinin düşük, orta veya yüksek olması şeklinde farklı risk koşulları göz önünde tutulmuştur. Böylece, farklı koşullara sahip 27 adet bölge için kuyu yöntemi ile diyafram duvar yapım maliyeti analizleri gerçekleştirilmiştir. Maliyet hesaplarının gerçekleştirilmesinde, Türkiye Bina Deprem Yönetmeliği esasları ve Çevre Şehircilik Bakanlığı 2021 birim fiyatları kullanılmıştır. Diyafram duvarın boyutları ve metraj hesaplamaları için İstCAD 2021 yazılım programı kullanılmış ve her bir koşul için analizler gerçekleştirilmiştir. Elde edilen sonuçlar, literatürde bulunan çalışmalar ile kıyaslanarak, diyafram duvar yapımının hangi koşullar için daha ekonomik olacağı belirlenmeye çalışılmıştır. Çalışma verileri, deprem riskinin maliyetlerde önemli değişiklikler yaptığını göstermektedir.

\section{INTRODUCTION}

Foundations are the structural elements responsible for transferring the structural loads to the ground, and there is an important relationship between foundation type, soil class and structure dimensions $[1,2,3]$. It has been determined by numerical analysis in previous research that the type of foundation and the relative displacement rates which, especially in the upper floors of the building, occur differently in different soil classes [4]. On the other hand, it is stated that excessive costly choices are made in order to stay in the safe zone during the foundation design stages of the construction [5]. For 
these reasons, the determination of the geotechnical properties of the soils in the region to be worked will be effective in the economic as well as the safety of the foundation design to be made.

The rapid population growth in the urban areas, the increase in the number of buildings and the rapid decrease of the empty parcels in city centres cause an increase in the cost of land, while limiting the building volumes in accordance with the building by laws [6, 7]. For these reasons, it is necessary to use smaller areas more efficiently in the design of buildings [8]. In other words, it is necessary to design higher structures in narrower spaces. However, this requirement causes a different problem, which is the depth of excavation. Deep excavations are required in order to bear the stresses of multi-storey structures built in narrow areas on the soil safely. The presence of other structures around narrow areas where deep excavations are required creates a very difficult process in terms of the engineering, the labour and the cost. In terms of the engineering, there is a risk of stability that may occur due to excavation, which may cause damage or even collapse of the surrounding buildings. Since the labour and equipment needs increase, the cost will increase, as well.

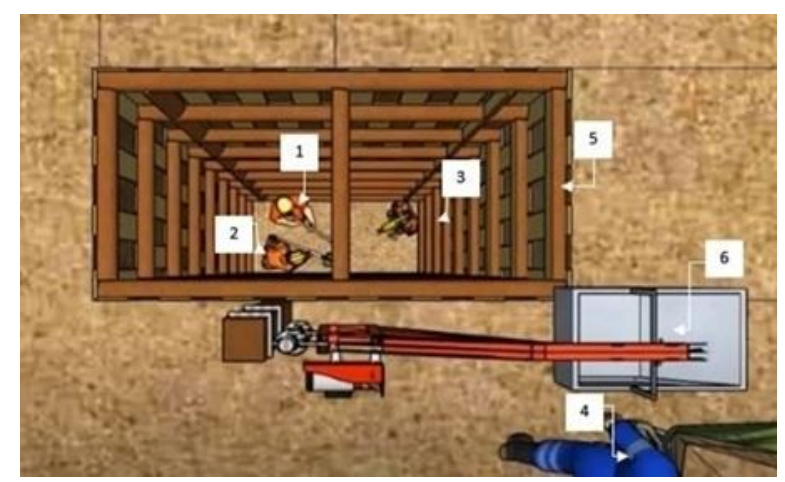

Figure 1. The well foundation excavation system [9]

Diaphragm wall by the well method could be considered as the most economical solution for these problems [10]. The diaphragm walls are mainly used for retaining walls. Standard methods of constructing retaining walls require temporary formwork and supports. Whereas, using diaphragm wall construction eliminates the need for formwork and temporary support and also allows above ground construction to proceed along with basement construction. Furthermore, in diaphragm wall designs by the well method, the geotechnical properties of the soil that will bear the structural load, the lateral pressures behind the wall and the earthquake risk of the area where the foundation is built are the most important factors that play a role in the dimensioning of the wall. Well foundations, which are a type of deep foundation, are built by trenching by manpower. For this reason, diaphragm wall by the well method offers a solution for narrow areas where excavation machines are not able to work [11].

Diaphragm walls constructed by the well method are generally prepared with average of 4 people in each well. Figure 1 shows a representative example of excavation made by the well method. While 3 of workers marked as 1,2 and 3 trench the well, the other marked as 4 removes the excavation by an elevator carrying device marked as 6 . The excavation is carried out simultaneously with the support system (the reinforcement) made using wood or steel material. After the excavation is completed, reinforcement placement on diaphragm walls is carried out by manpower, as in excavation works. Thus, the first stage (panel) of the wall, which is being built by the well method marked as 5 in Figure 1 and marked as 8 in Figure 2 (a), is completed.

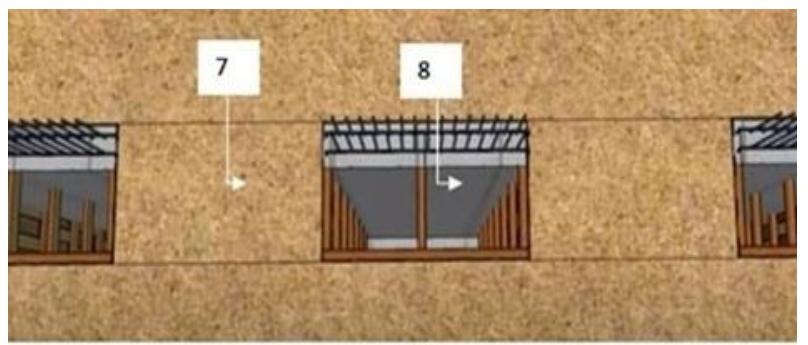

(a)

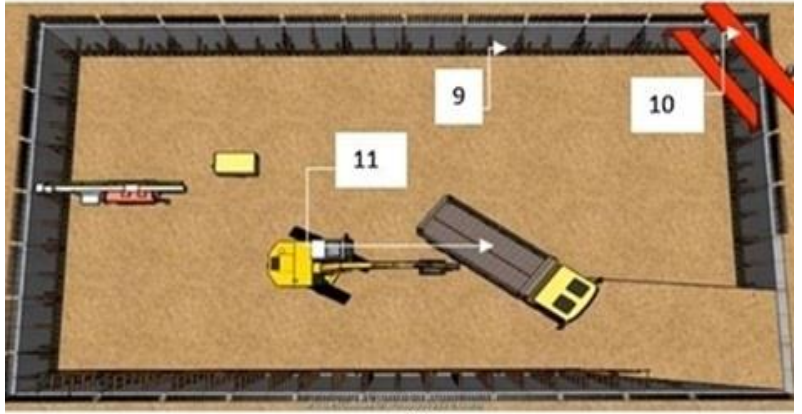

(b)

Figure 2. (a) Construction of diaphragm wall by the well method b) Completed version of the diaphragm wall [9]

The dimensions of each panel are 2 meters by 3 meters. The wells are trenched discontinuously as seen in Figure 2 (a). In other words, a diaphragm wall is a reinforced concrete structure constructed in-situ panel by panel. The in-between parts marked as 7 are then excavated and combined with the first wells marked as 8 . The first wells trenched are called main wells. Reinforcement placement, mold making and cast concrete operations are carried out in the main wells. Then the same procedures are carried out in the adjacent wells. In this stage of application, the side reinforcement sprouts left in the main well are combined with the adjacent wells' reinforcement. Thus, horizontal continuity is ensured in the walls. It is shown the wall that was assembled into a whole after being prepared in panels and marked as 9 in Figure 2(b). Finally, diaphragm walls are obtained by the well method. The anchorage and steel systems which is marked 10 in Figure 2(b), could be set up to support the further excavation works. Hence, the foundation excavation of building could be started in the area between the walls by a truck which is marked as 11 in Figure 2 (b) [9]. The constructed walls can be used as the load-bearing walls of the building, as well as in the insulation of the building through detail corrections. For these reasons, diaphragm walls constructed by the well method can be considered as the most suitable method for deep foundation construction in narrow spaces [12, 13]. It can be considered as a suitable system for the 
stability of the soil and the safety of the surrounding structures. This method helps to maintain the balance even when the groundwater level is close to the surface and makes it possible to go down to the desired excavation depth [14].

In this study, some analyses were made on the cost of the diaphragm wall construction by the well method in areas with different earthquake risk and on soils with different geotechnical properties. In the study, attention was paid to the selection of cohesive soils. The cost analyses in the literature and performed on non-cohesive soils [8] were taken as reference. Thus, the relationship between the earthquake risk and the cost of the well method in cohesive and non-cohesive soils has been tried to be revealed.

\section{MATERIALS AND METHOD}

In the study, 27 different conditions were studied in terms of the earthquake risks and the geotechnical properties. Details on the geotechnical properties of soils are presented in Table 1, Table 2 and Table 3. The selected soil samples were chosen to represent both cohesive soils and non-cohesive soils. Therefore, lowplasticity clay soil (CL) for representing cohesive soil and clayey sand (SC) for representing non-cohesive soil were selected according to the unified soil classification system (USCS). In the sampling, a well graded gravel (GW) soil, which data were obtained from the literature, also was used [8]. Thus, it was studied on a total of three different soil classes. 9 different situations of soils in these three different classes are considered. The relative density (Dr) was chosen such as $100 \%$ (high density), $50 \%$ (moderately density) and 0\% (low density) for noncohesive soils. Three different degrees of compaction were used for cohesive soils: non-compacted, moderately compacted and well-compacted.

Table 1. Geotechnical parameters used for the region with low earthquake risk (Karaman)

\begin{tabular}{cccccccccc}
\hline No & E.R. & Ss & USCS & $\begin{array}{c}* \text { Dr } \\
/ \text { Density }\end{array}$ & $\begin{array}{c}\mathbf{c} \\
\left(\mathbf{t m}^{-2}\right)\end{array}$ & $\begin{array}{c}\phi \\
\left({ }^{\circ}\right)\end{array}$ & $\begin{array}{c}\mathbf{\delta} \\
\left({ }^{(}\right)\end{array}$ & $\begin{array}{c}\mathbf{g}_{\text {sat }} \\
\left(\mathbf{t m}^{-3}\right)\end{array}$ & $\begin{array}{c}\mathbf{w} \\
(\%)\end{array}$ \\
\hline 1 & Low & 0.233 & CL & 0 & 0.68 & 0.00 & 0.00 & 1.43 & 1.0 \\
2 & Low & 0.233 & CL & 50 & 0.72 & 0.00 & 0.00 & 1.73 & 1.0 \\
3 & Low & 0.233 & CL & 100 & 3.34 & 0.00 & 0.00 & 1.99 & 1.0 \\
4 & Low & 0.233 & SC & 0 & 0.68 & 11.18 & 7.45 & 1.43 & 1.0 \\
5 & Low & 0.233 & SC & 50 & 0.72 & 26.61 & 17.74 & 1.73 & 1.0 \\
6 & Low & 0.233 & SC & 100 & 3.34 & 27.56 & 18.37 & 1.99 & 1.0 \\
7 & Low & 0.233 & GW & 0 & 0 & 28.00 & 18.67 & 1.85 & 1.0 \\
8 & Low & 0.233 & GW & 50 & 0 & 36.50 & 24.33 & 2.18 & 1.0 \\
9 & Low & 0.233 & GW & 100 & 0 & 45.00 & 30.00 & 2.34 & 1.0
\end{tabular}

*Dr for non-cohesive soils, Density for cohesive soils. E.R: Earthquake risk; Ss: Average values of the specified provinces; USCS: Unified soil classification system; Dr: Relative density, $\phi$ : Internal friction angle; $\delta$ : Wall-to-soil friction angle; $\gamma_{\text {sat }}$ : Saturated density; w: Water content.

The earthquake risks of the areas where the foundation will be constructed are also considered in the analysis. In the 2018 earthquake regulations, the term "earthquake risk" is used instead of the term "earthquake zone". In addition, as per the regulation, earthquake risks are determined separately on a parcel basis, not on a regional or district basis. In this study, three different districts were selected as representative in order to include areas with the high earthquake risk, medium earthquake risk and low earthquake risk in the calculations.

These districts are Duzce, Zonguldak and Karaman. Duzce district was used for representing the high earthquake risk, Zonguldak district was used for representing medium earthquake risk and Karaman district was used for representing low earthquake risk in the analysis. Thus, a total of 27 different conditions are determined by combining earthquake risks and geotechnical properties. The principles of the Turkish Building Earthquake Code (TBDY-2018) [15] were taken into account in the analysis. In line with these principles, the IstCAD-2021 software program was used, and analysis related to the diaphragm wall by the well method were carried out.

Table 2. Geotechnical parameters used for the region with medium earthquake risk (Zonguldak)

\begin{tabular}{cccccccccc}
\hline No & E.R. & Ss & USCS & $\begin{array}{c}{ }^{*} \text { Dr } \\
\text { /Density }\end{array}$ & $\begin{array}{c}\mathbf{c} \\
\left(\mathbf{t m}^{-2}\right)\end{array}$ & $\begin{array}{c}\phi \\
\left({ }^{\circ}\right)\end{array}$ & $\begin{array}{c}\mathbf{\delta} \\
\left({ }^{\circ}\right)\end{array}$ & $\begin{array}{c}\mathbf{g}_{\text {sat }} \\
\left(\mathbf{t m}^{-3}\right)\end{array}$ & $\begin{array}{c}\mathbf{w} \\
(\boldsymbol{\%})\end{array}$ \\
\hline 10 & Med & 0.528 & CL & 0 & 0.68 & 0 & 0 & 1.43 & 1.0 \\
11 & Med & 0.528 & CL & 50 & 0.72 & 0 & 0 & 1.73 & 1.0 \\
12 & Med & 0.528 & CL & 100 & 3.34 & 0 & 0 & 1.99 & 1.0 \\
13 & Med & 0.528 & SC & 0 & 0.68 & 11.18 & 7.45 & 1.43 & 1.0 \\
14 & Med & 0.528 & SC & 50 & 0.72 & 26.61 & 17.7 & 1.73 & 1.0 \\
15 & Med & 0.528 & SC & 100 & 3.34 & 27.56 & 18.4 & 1.99 & 1.0 \\
16 & Med & 0.528 & GW & 0 & 0 & 28 & 18.7 & 1.85 & 1.0 \\
17 & Med & 0.528 & GW & 50 & 0 & 36.5 & 24.3 & 2.18 & 1.0 \\
18 & Med & 0.528 & GW & 100 & 0 & 45 & 30 & 2.34 & 1.0
\end{tabular}

*Dr for non-cohesive soils, Density for cohesive soils. E.R: Earthquake risk; Med: Medium; Ss: Average values of the specified provinces; USCS: Unified soil classification system; Dr: Relative density, $\phi$ Internal friction angle; $\delta$ : Wall-to-soil friction angle; $\gamma_{\text {sat }}$ : Saturated density; w: Water content.

The earthquake parameters of the selected districts in the analyses were calculated using the coefficients given by the Turkey Earthquake Hazard Maps, which entered into force on $22^{\text {nd }} / 01 / 2018$. Since these coefficients are on the basis of parcels, the average value for each district was used.

Table 3. Geotechnical parameters used for the region with the high earthquake risk (Duzce)

\begin{tabular}{lccccccccc}
\hline No & E.R. & Ss & USCS & $\begin{array}{c}* \text { Dr } \\
\text { /Density }\end{array}$ & $\begin{array}{c}\mathbf{c} \\
\left(\mathbf{t m}^{-2}\right)\end{array}$ & $\begin{array}{c}\phi \\
\left({ }^{\circ}\right)\end{array}$ & $\begin{array}{c}\boldsymbol{\delta} \\
\left({ }^{\circ}\right)\end{array}$ & $\begin{array}{c}\gamma_{\text {sat }} \\
\left(\mathbf{t m}^{-3}\right)\end{array}$ & $\begin{array}{c}\mathbf{w} \\
(\boldsymbol{\%})\end{array}$ \\
\hline 10 & High & 1.342 & CL & 0 & 0.68 & 0 & 0 & 1.43 & 1.0 \\
11 & High & 1.342 & CL & 50 & 0.72 & 0 & 0 & 1.73 & 1.0 \\
12 & High & 1.342 & CL & 100 & 3.34 & 0 & 0 & 1.99 & 1.0 \\
13 & High & 1.342 & SC & 0 & 0.68 & 11.18 & 7.45 & 1.43 & 1.0 \\
14 & High & 1.342 & SC & 50 & 0.72 & 26.61 & 17.7 & 1.73 & 1.0 \\
15 & High & 1.342 & SC & 100 & 3.34 & 27.56 & 18.4 & 1.99 & 1.0 \\
16 & High & 1.342 & GW & 0 & 0 & 28 & 18.7 & 1.85 & 1.0 \\
17 & High & 1.342 & GW & 50 & 0 & 36.5 & 24.3 & 2.18 & 1.0 \\
18 & High & 1.342 & GW & 100 & 0 & 45 & 30 & 2.34 & 1.0 \\
\hline
\end{tabular}

*Dr for non-cohesive soils, Density for cohesive soils. E.R: Earthquake risk; Ss: Average values of the specified provinces; USCS: Unified soil classification system; Dr: Relative density, $\phi$ : Internal friction angle; $\delta$ : Wall-to-soil friction angle; $\gamma_{\mathrm{sat}}$ : Saturated density; w: Water content.

Calculations are based on ZC as the local soil class. Thus, the "Short period map spectral acceleration coefficient" (Ss) was determined such as 1.342 for the high earthquake risk (Duzce); 0.528 for medium 
earthquake risk (Zonguldak); and 0.233 for low earthquake risk (Karaman). Likewise, the "Local soil effect coefficient" (FS) was determined such as 1.20 for Duzce; 1.29 for Zonguldak; and 1.3 for Karaman. Finally, the "Design spectral acceleration coefficient" (SDS) was calculated such as 1.61 for Duzce are: 1.61; 0.68 for Zonguldak and 0.30 for Karaman.

The earthquake parameters to be used in the calculations and the geotechnical properties of the soils in the foundation area were processed by using the well foundation module of the IstCAD-2021 software program. The analysis were carried out according to the TBDY-2018 principles. In the first stage of the calculations, the well dimensions were determined by using the model shown in Figure 3. Then, soil bearing capacity, shear strength control, rollover control and collapse analysis were calculated with IstCAD-2021. In addition, reinforced concrete calculations were carried out in according with "TS 500". The friction angle between the wall and the soil $(\delta)$ was calculated by $2 / 3 \varphi$ approximation. The class of concrete and the steel class were chosen as $\mathrm{C} 30$ and $\mathrm{S} 420$ (ribbed reinforcement) respectively. Quantity (materials) calculations were calculated according to the determined dimensions of the wall. The cost analysis was calculated according to the "Unit Prices of the Ministry of Environment and Urbanization for 2021" (UP-MEU/2021).

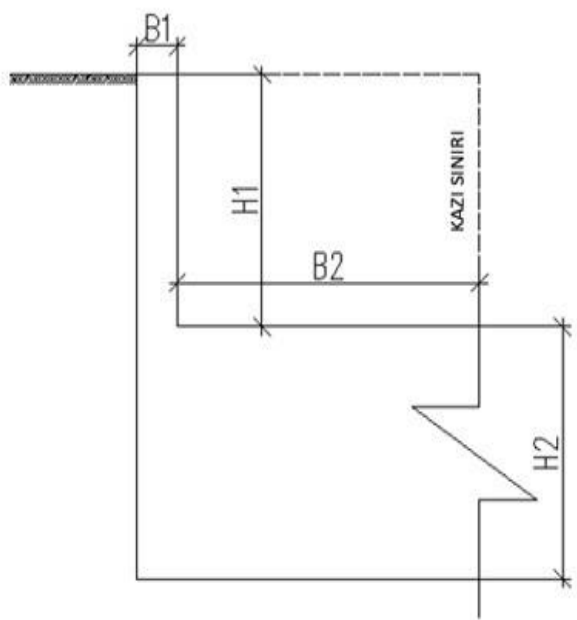

Figure 3. The section used in the calculations

\section{RESULTS AND DISCUSSION}

The examinations and calculations listed in the material and method section were carried out separately for each condition. The dimensions of the diaphragm wall in the model were coded as fallow: The height of the wall as $\mathrm{H} 1$, the thickness of the wall as B1, the length of the wall footing as B2, and the thickness of well footing as $\mathrm{H} 2$, as seen in Figure 3. The footing is the extended, protruding section of the walls and reinforced concrete columns that rests on the soil. $\mathrm{H} 1$ was chosen as $3.00 \mathrm{~m}$ and the other dimensions such as $\mathrm{B} 1, \mathrm{~B} 2$ and $\mathrm{H} 2$ were determined according to the geotechnical properties of the soil behind the wall as presented in Table 4.
The cost analysis were carried out according to the TBDY-2018 principles by means of the IstCAD 2021 software program for 27 different conditions. Besides, UP-MEU/2021 were taken as a reference in the analysis. The shear force and moment values for reinforced concrete were calculated by using the obtained data from Table 4. Then, the concrete, the reinforcement, the formwork and the excavation quantities were calculated according to shear force and moment values. The quantity (materials) of the diaphragm wall by the well method were determined according to the earthquake risk and soil properties of the region are presented in Table 5.

Table 4. Foundation section dimensions according to geotechnical properties and earthquake risk

\begin{tabular}{|c|c|c|c|c|c|c|c|}
\hline $\begin{array}{c}\text { Earthquake } \\
\text { Risk. }\end{array}$ & Ss & $\begin{array}{c}* \text { Dr } \\
\text { /Density }\end{array}$ & USCS & $\begin{array}{c}\text { B1 } \\
(\mathbf{c m})\end{array}$ & $\begin{array}{c}\text { H1 } \\
(\mathbf{c m})\end{array}$ & $\begin{array}{c}\text { B2 } \\
(\mathbf{c m})\end{array}$ & $\begin{array}{r}\mathrm{H} 2 \\
(\mathrm{~cm})\end{array}$ \\
\hline \multirow{3}{*}{$\begin{array}{c}\text { High } \\
\text { (Duzce) }\end{array}$} & \multirow{3}{*}{1.342} & 0 & \multirow{9}{*}{ CL } & 100 & 300 & 1600 & 500 \\
\hline & & 50 & & 100 & 300 & 1130 & 500 \\
\hline & & 100 & & 30 & 300 & 30 & 200 \\
\hline \multirow{3}{*}{$\begin{array}{c}\text { Medium } \\
\text { (Zonguldak) }\end{array}$} & \multirow{3}{*}{0.528} & 0 & & 60 & 300 & 190 & 200 \\
\hline & & 50 & & 40 & 300 & 160 & 200 \\
\hline & & 100 & & 20 & 300 & 30 & 200 \\
\hline \multirow{3}{*}{$\begin{array}{c}\text { Low } \\
\text { (Karaman) }\end{array}$} & \multirow{3}{*}{0.233} & 0 & & 60 & 300 & 195 & 200 \\
\hline & & 50 & & 45 & 300 & 150 & 200 \\
\hline & & 100 & & 20 & 300 & 30 & 200 \\
\hline \multirow{3}{*}{$\begin{array}{c}\text { High } \\
\text { (Duzce) }\end{array}$} & \multirow{3}{*}{1.342} & 0 & \multirow{9}{*}{ GW } & 100 & 300 & 2150 & 650 \\
\hline & & 50 & & 70 & 300 & 490 & 220 \\
\hline & & 100 & & 45 & 300 & 215 & 200 \\
\hline \multirow{3}{*}{$\begin{array}{c}\text { Medium } \\
\text { (Zonguldak) }\end{array}$} & \multirow{3}{*}{0.528} & 0 & & 45 & 300 & 175 & 200 \\
\hline & & 50 & & 30 & 300 & 135 & 200 \\
\hline & & 100 & & 25 & 300 & 65 & 200 \\
\hline \multirow{3}{*}{$\begin{array}{c}\text { Low } \\
\text { (Karaman) }\end{array}$} & \multirow{3}{*}{0.233} & 0 & & 45 & 300 & 150 & 200 \\
\hline & & 50 & & 40 & 300 & 100 & 200 \\
\hline & & 100 & & 20 & 300 & 300 & 200 \\
\hline \multirow{3}{*}{$\begin{array}{c}\text { High } \\
\text { (Duzce) }\end{array}$} & \multirow{3}{*}{1.342} & 0 & \multirow{9}{*}{$\mathrm{SC}$} & 100 & 300 & 1250 & 500 \\
\hline & & 50 & & 100 & 300 & 900 & 500 \\
\hline & & 100 & & 30 & 300 & 220 & 200 \\
\hline \multirow{3}{*}{$\begin{array}{c}\text { Medium } \\
\text { (Zonguldak) }\end{array}$} & \multirow{3}{*}{0.528} & 0 & & 20 & 300 & 65 & 200 \\
\hline & & 50 & & 20 & 300 & 50 & 200 \\
\hline & & 100 & & 20 & 300 & 40 & 200 \\
\hline \multirow{3}{*}{$\begin{array}{c}\text { Low } \\
\text { (Karaman) }\end{array}$} & \multirow{3}{*}{0.233} & 0 & & 20 & 300 & 40 & 200 \\
\hline & & 50 & & 20 & 300 & 35 & 200 \\
\hline & & 100 & & 20 & 300 & 30 & 200 \\
\hline
\end{tabular}

*Dr for non-cohesive soils, Density for cohesive soils

The cost estimation was calculated by using the UPMEU/2021 and the quantities determined. The results are presented in Table 6 . The materials and labour were included but shipping costs are not included in the cost estimation.

The effect of the soil properties and the earthquake risk on the total costs of the diaphragm wall by well method is presented in Figure 4, Figure 5 and Figure 6. Figure 4 shows the total cost amounts according to the low-risk earthquake zone and soil class, besides the details of the total cost such as excavation, formwork, concrete, thick and thin reinforcement. According to the Figure 4, the minimum total cost is 26.66 thousand $\mathrm{E}$ for the low-risk earthquake zone. This cost is the same for five different soil conditions such as non-compacted CL, moderately compacted CL, well-compacted CL, loose GW, moderately density SC. It is 39.62 thousand $€$ for loose SC, 47.98 thousand $€$ for high-density SC and moderately density GW. The maximum cost belong to 
the wall built on the high-density GW soils as 60.26 thousand $₹$. There is a 2.3 times difference between the lowest cost and the highest cost. The most important factor in this increase is concrete and reinforcement costs.

Table 5. The quantity of the diaphragm wall according to the earthquake risk and soil properties of the region

\begin{tabular}{|c|c|c|c|c|c|c|c|c|}
\hline E. R. & Ss & $\begin{array}{c}* \text { Dr } \\
/ \\
\text { Density }\end{array}$ & USCS & $\begin{array}{c}\mathbf{R} \\
\text { (thin } \\
\text { ) (kg) }\end{array}$ & $\begin{array}{c}\mathbf{R} \\
\text { (thick) } \\
\text { (kg) }\end{array}$ & $\underset{\left(\mathbf{m}^{3}\right)}{\mathbf{C}}$ & $\underset{\left(\mathbf{m}^{2}\right)}{\mathbf{F}}$ & $\begin{array}{c}\mathbf{T} \\
\left(\mathbf{m}^{3}\right)\end{array}$ \\
\hline \multirow{3}{*}{$\begin{array}{l}\text { High } \\
\text { (Duzce) }\end{array}$} & & 0 & \multirow{9}{*}{ CL } & 2926 & 57126 & 1245 & 406 & 1920 \\
\hline & 1.342 & 50 & & 2491 & 31897 & 893 & 359 & 1356 \\
\hline & & 100 & & 482 & 687 & 18 & 152 & 23 \\
\hline \multirow{3}{*}{$\begin{array}{c}\text { Medium } \\
\text { (Zonguldak) }\end{array}$} & \multirow{3}{*}{0.528} & 0 & & 784 & 2038 & 84 & 161 & 143 \\
\hline & & 50 & & 586 & 1443 & 65 & 183 & 120 \\
\hline & & 100 & & 482 & 687 & 18 & 152 & 23 \\
\hline \multirow{3}{*}{$\begin{array}{c}\text { Low } \\
\text { (Karaman) }\end{array}$} & \multirow{3}{*}{0.233} & 0 & & 786 & 2050 & 86 & 161 & 146 \\
\hline & & 50 & & 606 & 1428 & 65 & 159 & 113 \\
\hline & & 100 & & 482 & 687 & 18 & 152 & 23 \\
\hline \multirow{3}{*}{$\begin{array}{c}\text { High } \\
\text { (Duzce) }\end{array}$} & \multirow{3}{*}{1.342} & 0 & \multirow{9}{*}{ GW } & 4431 & 107366 & 2141 & 571 & 3064 \\
\hline & & 50 & & 2111 & 5678 & 193 & 182 & 382 \\
\hline & & 100 & & 693 & 1883 & 85 & 161 & 161 \\
\hline \multirow{3}{*}{$\begin{array}{c}\text { Medium } \\
\text { (Zonguldak) }\end{array}$} & \multirow{3}{*}{0.528} & 0 & & 627 & 1597 & 73 & 160 & 131 \\
\hline & & 50 & & 932 & 659 & 54 & 157 & 101 \\
\hline & & 100 & & 733 & 533 & 31 & 154 & 49 \\
\hline \multirow{3}{*}{$\begin{array}{c}\text { Low } \\
\text { (Karaman) }\end{array}$} & \multirow{3}{*}{0.233} & 0 & & 606 & 1428 & 65 & 159 & 113 \\
\hline & & 50 & & 896 & 705 & 48 & 156 & 75 \\
\hline & & 100 & & 482 & 687 & 18 & 152 & 23 \\
\hline \multirow{3}{*}{$\begin{array}{c}\text { High } \\
\text { (Duzce) }\end{array}$} & \multirow{3}{*}{1.342} & 0 & \multirow{7}{*}{$\mathrm{SC}$} & 2491 & 39260 & 983 & 371 & 1500 \\
\hline & & 50 & & 6458 & 17886 & 720 & 336 & 1080 \\
\hline & & 100 & & 1099 & 1187 & 80 & 161 & 165 \\
\hline \multirow{3}{*}{$\begin{array}{c}\text { Medium } \\
\text { (Zonguldak) }\end{array}$} & \multirow{3}{*}{0.528} & 0 & & 597 & 687 & 29 & 154 & 49 \\
\hline & & 50 & & 517 & 687 & 24 & 153 & 38 \\
\hline & & 100 & & 494 & 687 & 21 & 153 & 30 \\
\hline Low & 0.233 & 0 & & 495 & 687 & 21 & 157 & 30 \\
\hline
\end{tabular}

$\begin{array}{lcccccc}\text { (Karaman) } & 50 & 488 & 687 & 20 & 153 & 26 \\ & 100 & 482 & 687 & 18 & 152 & 23\end{array}$

E.R: Earthquake risk; R: Reinforcement; C: Concrete; F: Formwork; T: Trench

Figure 5 shows the total cost amounts according to the medium -risk earthquake zone and soil class, besides the details of the total cost such as excavation, formwork, concrete, thick and thin reinforcement. According to the Figure 5, the minimum total cost is 26.66 thousand $€$ for the medium -risk earthquake zone. This cost belong to the wall built on the moderately density SC soil. The order of cost increase is as follows in thousand $€$ : loose $\mathrm{GW}$ as 27.71 , moderately density $\mathrm{GW}$ as 28.84 , loose SC as 30.88 , non-compacted CL as 31,43 , moderately compacted CL as 41.25, well-compacted SC as 49.92, well-compacted GW as 51.78. and CL. The maximum cost belong to the wall built on the high-density wellcompacted CL soils as 59.67 thousand $€$. There is a 2.3 times difference between the lowest cost and the highest cost. The most important factor in this increase is concrete and reinforcement costs just as the lowearthquake risk zone.

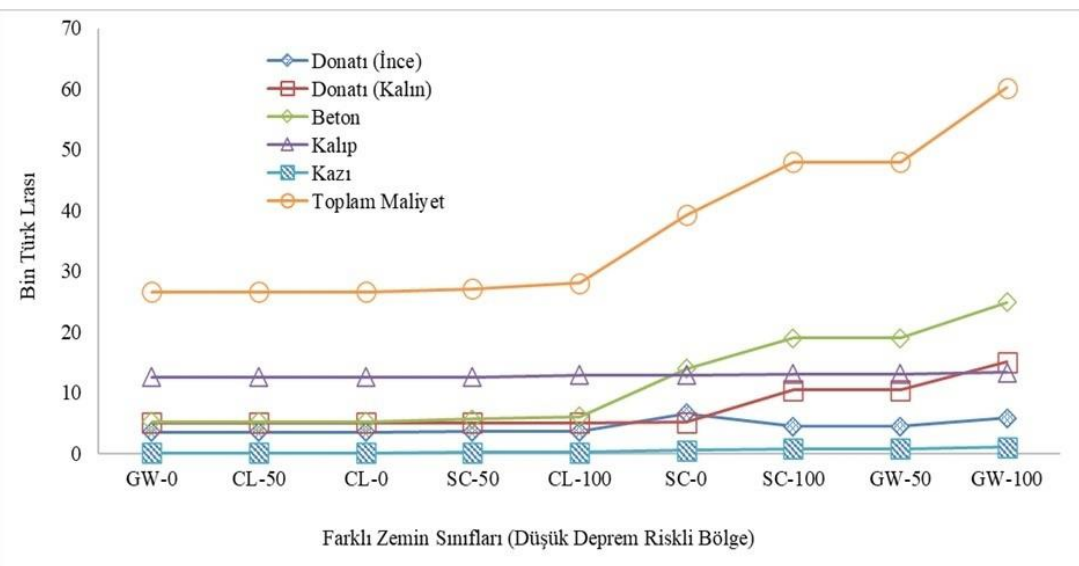

Figure 4. Variation of diaphragm wall by the well method costs according to the different geotechnical parameters in low-risk zones.

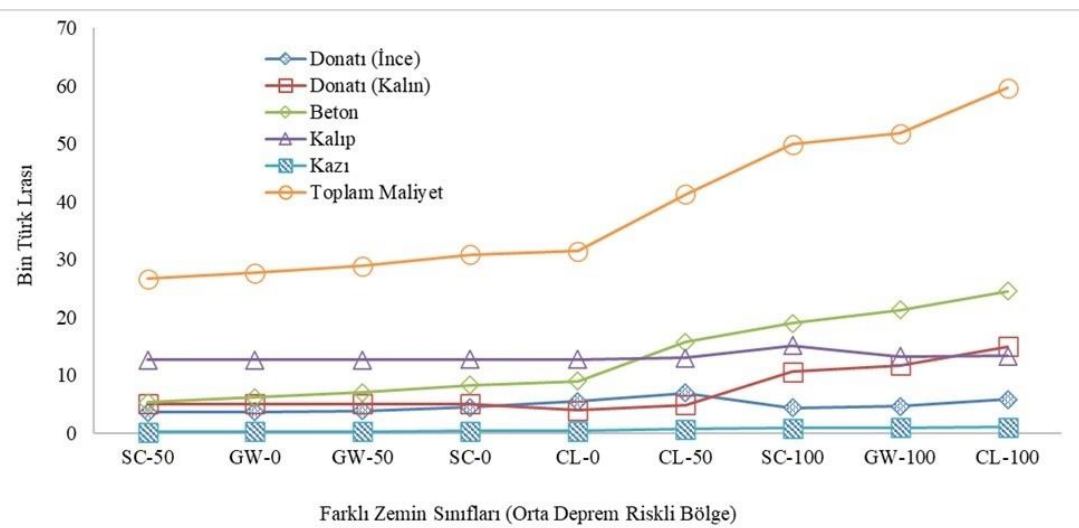

Figure 5. Variation of diaphragm wall by the well method costs according to the different geotechnical parameters in medium-risk earthquake zones.

The total costs of the diaphragm walls to be built in the high-risk earthquake zone and the costs of excavation, formwork, concrete, thick and thin reinforcement that play a role in it are seen in Figure 6. It is seen that the lowest cost is 26.66 thousand $€$ and belong to high- density GW in the high-risk earthquake zone. The ordered cost list from the minimum to maximum is as fallows in thousand $\mathrm{z}$ : well compacted GW, noncompacted CL as 54.54, loose GW as 58.22, moderately compacted CL as 131.57, loose SC as 425,09, high 
density SC as 552,9, medium compacted GW as 635.4, well compacted CL as 825.50. The maximum cost is 1516.50 and belong to the wall built on moderately compacted SC soil. There is a difference around 57 times between the highest and lowest costs of the diaphragm walls to be built in the high-risk earthquake zone. The most important factor in this increase is concrete and reinforcement costs.

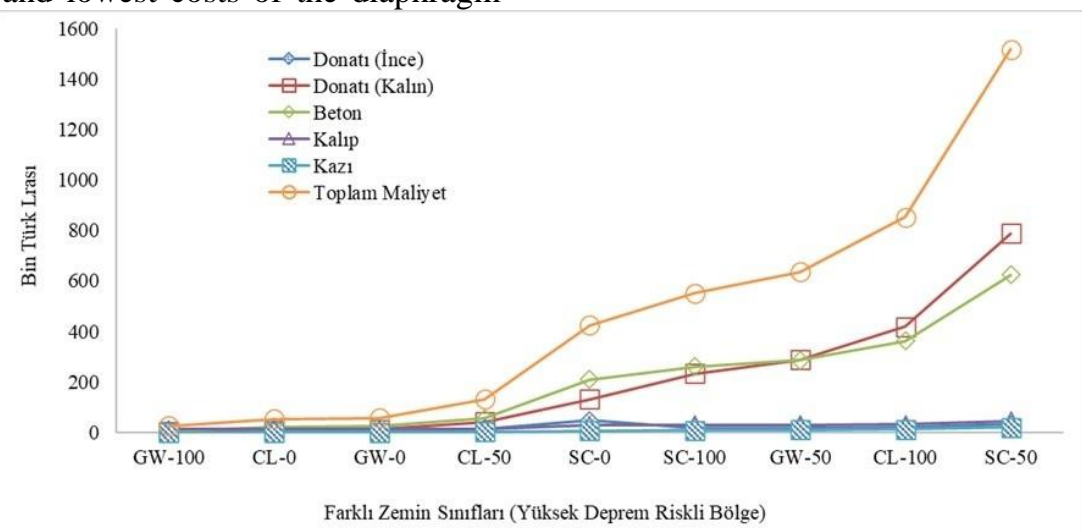

Figure 6. Variation of diaphragm wall by the well method costs according to the different geotechnical parameters in high-risk earthquake zones.

Table 6. Wall costs determined as a result of the analysis

\begin{tabular}{|c|c|c|c|c|c|c|c|c|}
\hline \multirow{2}{*}{\multicolumn{3}{|c|}{ Unit prices and cost analysis }} & \multirow{2}{*}{ 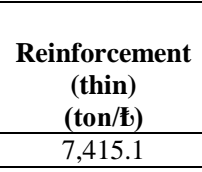 } & \multicolumn{3}{|c|}{ Unit Prices for 2021} & \multirow{2}{*}{$\begin{array}{c}\begin{array}{c}\text { Excavation } \\
\left(\mathbf{m}^{\mathbf{3}} / \mathbf{f}\right)\end{array} \\
7.1 \\
\end{array}$} & \multirow{4}{*}{ Total Cost } \\
\hline & & & & $\begin{array}{c}\text { Reinforcement } \\
\text { (thick) } \\
\text { (ton/f) }\end{array}$ & $\begin{array}{c}\text { Concrete } \\
\left(\mathbf{m}^{3} / \mathbf{t}\right)\end{array}$ & $\begin{array}{c}\text { Formwork } \\
\left(\mathbf{m}^{2} / \mathbf{t}\right)\end{array}$ & & \\
\hline \multirow[b]{2}{*}{$\begin{array}{c}\text { Earthquake } \\
\text { Risk }\end{array}$} & \multirow[b]{2}{*}{$\begin{array}{c}\text { *Dr/ } \\
\text { Density }\end{array}$} & \multirow[b]{2}{*}{ USCS } & & \multicolumn{2}{|c|}{ Total Cost (f) } & & & \\
\hline & & & $\begin{array}{c}\text { Reinforcement } \\
\text { (thin) }\end{array}$ & $\begin{array}{c}\text { Reinforcement } \\
\text { (thick) }\end{array}$ & Concrete & Formwork & Trench & \\
\hline \multirow{3}{*}{ High (Duzce) } & 0 & \multirow{9}{*}{$\mathrm{CL}$} & 3577 & 5052 & 5255 & 12616 & 160 & 26659 \\
\hline & 50 & & 18470 & 234573 & 260556 & 29718 & 9614 & 552931 \\
\hline & 100 & & 21695 & 420109 & 363465 & 33609 & 13613 & 852491 \\
\hline \multirow{3}{*}{$\begin{array}{c}\text { Medium } \\
\text { (Zonguldak) }\end{array}$} & 0 & & 3577 & 5052 & 5255 & 12616 & 160 & 26659 \\
\hline & 50 & & 4348 & 10611 & 18976 & 15132 & 851 & 49919 \\
\hline & 100 & & 5812 & 14985 & 24523 & 13344 & 1010 & 59674 \\
\hline \multirow{3}{*}{$\begin{array}{c}\text { Low } \\
\text { (Karaman) }\end{array}$} & 0 & & 3577 & 5052 & 5255 & 12616 & 160 & 26659 \\
\hline & 50 & & 4491 & 10500 & 19049 & 13137 & 798 & 47975 \\
\hline & 100 & & 5826 & 15073 & 24961 & 13361 & 1037 & 60257 \\
\hline \multirow{3}{*}{$\begin{array}{c}\text { High } \\
\text { (Duzce) }\end{array}$} & 0 & \multirow{9}{*}{$\mathrm{SC}$} & 8146 & 8726 & 23209 & 13286 & 1170 & 54537 \\
\hline & 50 & & 47887 & 131536 & 210197 & 27814 & 7657 & 425091 \\
\hline & 100 & & 18470 & 288725 & 286831 & 30711 & 10635 & 635372 \\
\hline \multirow{3}{*}{$\begin{array}{c}\text { Medium } \\
\text { (Zonguldak) }\end{array}$} & 0 & & 3661 & 5052 & 6131 & 12649 & 213 & 27705 \\
\hline & 50 & & 3835 & 5052 & 7007 & 12682 & 266 & 28841 \\
\hline & 100 & & 4426 & 5052 & 8320 & 12732 & 346 & 30875 \\
\hline \multirow{3}{*}{$\begin{array}{c}\text { Low } \\
\text { (Karaman) }\end{array}$} & 0 & & 3577 & 5052 & 5255 & 12616 & 160 & 26659 \\
\hline & 50 & & 3619 & 5052 & 5693 & 12632 & 186 & 27182 \\
\hline & 100 & & 3671 & 5052 & 6131 & 12980 & 213 & 28046 \\
\hline \multirow{3}{*}{$\begin{array}{l}\text { High } \\
\text { (Duzce) }\end{array}$} & 0 & \multirow{9}{*}{ GW } & 32856 & 789581 & 625117 & 47226 & 21722 & 1516501 \\
\hline & 50 & & 15654 & 41759 & 56403 & 15046 & 2710 & 131572 \\
\hline & 100 & & 5142 & 13845 & 24742 & 13352 & 1143 & 58225 \\
\hline \multirow{3}{*}{$\begin{array}{l}\text { Medium } \\
\text { (Zonguldak) }\end{array}$} & 0 & & 4651 & 11744 & 21239 & 13220 & 931 & 51784 \\
\hline & 50 & & 6910 & 4849 & 15765 & 13013 & 718 & 41255 \\
\hline & 100 & & 5435 & 3917 & 8977 & 12756 & 346 & 31432 \\
\hline \multirow{3}{*}{$\begin{array}{c}\text { Low } \\
\text { (Karaman) }\end{array}$} & 0 & & 4491 & 10500 & 19049 & 13137 & 798 & 47975 \\
\hline & 50 & & 6641 & 5187 & 14013 & 12947 & 532 & 39319 \\
\hline & 100 & & 3577 & 5052 & 5255 & 12616 & 160 & 26659 \\
\hline
\end{tabular}

\section{CONCLUSION}

In this study, the effects of the factors such as soil class in the area and earthquake risk on the cost of the diaphragm wall by well method are discussed. The IstCAD 2021 software program, the Turkish Building Earthquake Regulation Principles (TBDY-2018) and the UP-MEU/2021 were used for the analysis made.

The data obtained shows that diaphragm walls can be applied economically in low and medium risk earthquake zones. The geotechnical properties of the soil behind the wall do not create a significant change on the cost neither low nor medium risk earthquake zones. However, the geotechnical properties of the soil effect the costs considerably in regions with the highearthquake risk. The costs in this region is vary in a wide range from 26 thousand Turkish $€$ to 1 million 500 thousand $€$, depending on the geotechnical properties. The concrete and the reinforcement costs play the biggest role in this affect. 
The total costs of CL and SC soils analysed are in a range of 26 thousand and 60 thousand for medium and low-risk earthquake zones in all soil condition such as low, moderately or high density. CL and SC soils in loose condition in the high-risk area also have a cost in the same ranges. However, the cost is up to 850 thousand $\notin$ in the high earthquake risk zones on well-compacted conditions for SC and CL. Therefore, diaphragm wall application is far from economical on well-compacted clayey soils in the high earthquake risk areas.

The total cost of the diaphragm wall construction is in the range of 26 thousand and 51 thousand $€$ for medium and low risk earthquake zones on GW soils. However, it is up to 1.5 million $€$ in the high earthquake risk areas. Therefore, diaphragm wall application is far from economical on non-cohesive soils in the high earthquake risk areas.

According to the results obtained, the diaphragm wall application by the well method is able to be considered appropriate and economical to be applied in low and medium risk areas, regardless of soil conditions. However, this method is not appropriate and economical for the high earthquake risk zone. It is hoped that the data obtained in this study will contribute to the literature and encourage similar studies to the clarification of the subject.

\section{REFERENCES}

[1] Coduto DP, Geotechnical engineering: principles and practice. 2nd Edition, Pearson Education, California; 1999.

[2] Gör M, Aksoy SH, İnal E. Kazıklı temellerde yüzey sürtünme açısının hesabı için yeni bir abak önerisi. 3rd International Soil-Structure Interaction Symposium 18-20 October. İzmir: Turkey; 2017. p. 101-107.

[3] Aksoy SH, Özpolat A, Gör M. Effect of excavation on settlements and bearing capacity of a foundation. Special Issue: XVI DECGE 2018 Proceedings of the 16th Danube-European conference on geotechnical engineering. 2018;2(23):561-566.

[4] Karabörk T. Yapı-toprak etkileşimi dikkate alınarak betonarme yapıların doğrusal olmayan 3 boyutlu dinamik analizi. Yap1 Teknolojileri Elektronik Dergisi. 2009;5(1):25-36.

[5] Arslan Ö, Keskin İ, Ateş A. İnşası tamamlanmış binaların ekomiklik ve güvenlik durumları göz önünde bulundurularak farklı temel türleri ile yeniden çözümünün karşılaştırmalı analizi. 2nd Int. Symp. Nat. Hazards Disaster Manag. Sakarya: Turkey; 2018. p. 572-581.

[6] Canpolat FA. Kentsel değişimin coğrafi boyutları: Elazığ örneği. Al Farabi Uluslararası Sos. Bilim. Derg. 2019;3(1):70-105.

[7] Özaydın E, Baz İ. Yeşil bina konseptinin kentsel dönüşüm uygulamalarında ele alınması. Teknol. ve Uygulamalı Bilim. Derg. 2021;3(2):203-216.
[8] Afşar E, Bilgen G. Kuyu temel maliyetinin deprem riskine göre değişimi. Tasarım Mimarlık ve Mühendislik Dergisi. 2021;1(3):181-188.

[9] Çubuk A. Diyafram duvar yapım yöntemi ve temel çukuru kazısı. Available from: https://www. youtube.com/ watch?v=sJpP5vpvn3M

[10] Bayram S, Öcal ME, Laptalı Oral E, Atış CD. Comparison of unit price method and unit area cost method for construction cost estimation. J. Polytech. Derg. 2016;19(2):175-183.

[11] Holtz R, Kovacs W, Sheahan T. Geoteknik mühendisliğine giriş. 2015.

[12] Özbey İ, Gör MA. Study on well foundations: well foundation analysis for attached buildings. IV. International icon-tech symposium on innovative surveys in positive sciences. Adana: Turkey; 2021. p. 248-261.

[13] Aksoy HS, Gör M, İnal E. Determination of friction angles between soil and steel-FRP piles. Turkish Journal of Science and Technology. 2018;13(1):1923.

[14] Herrmann H, Bucksch H. Soil mechanics and foundation engineering. 2014.

[15] TBDY-2018. Türkiye bina deprem yönetmeliği :2018. Available from: https://www.imo.org.tr/ resimler/dosya_ekler/89227ad223d3b7a_ek.pdf 